Исследование кинематики рабочего органа трала во время движения по минному полю с неровностями Р.А. Нанивский, А.В. Емельянов

В статье предложена модифицированная конструкция рабочего органа трала. Она относительно проста в комплектации, повышает не только его живучесть, но и при необходимости позволяет проводить замену наиболее уязвимого его элемента - рабочего диска. Конструкция рабочего органа трала в виде U-образного коромьсла с двумя рабочими дисками дает возможность эффективно эксплуатировать трал даже в случаях, когда один из рабочих дисков вышел из строя.

Описана кинематика основных частей рабочего органа для случая движения тральщика вдоль минного поля с неровностями с постоянной скоростью. Получены аналитические зависимости, определяющие основные параметры движения как самого U-образного рычага, так и рабочего диска.

Ключевые слова: минный трал, рабочий диск, кинематические параметры движения элементов трала.

Research of kinematics of the working body of the trawl while driving on a minefield with irregularities R. Nanivskyi, A. Yemelianov

During combat operations, troops increasingly use mine barriers (minefields) to get protection against sudden offensive or penetration of enemy sabotage groups. The safest and at the same time the fastest way of their clearance or breaching for military equipment and personnel is demining of areas or individual sections by means of mine trawls. The experience of their application shows a number of existing problems, which reduce the efficiency of their use during breaching a minefield. First and foremost, it's the low maneuverability of the minesweeper because of the large dimensions of the trawl and the lack of "survivability" of the individual trawl elements. This paper is devoted to the partial solution of this problem, namely increasing the maneuverability of mine trawl by modernizing trawl working point. The article proposes a modified design of the trawl working body, which is much simpler than the existing, that in turn allows the minesweeper to demonstrate higher maneuverability. The proposed design of the trawl working body in the form of a $U$-shaped rocker with two working disks makes it possible to efficiently operate the trawl, even in cases where one of the working disks has been out of order.

The paper describes the kinematics of the main parts of the working body for the case of the minesweeper's movement through the minefield, taking into account the unevenness of the varied terrain with a constant speed. The analytical dependences are obtained, which determine the basic movement parameters as of the U-shaped rocker of the working disk. By their analysis it is established: depending on the magnitude of the unevenness' lifting angles of the mine trawl during running of the working disk over it, the U-shaped rocker can rotate around its axis in both directions (clockwise and anticlockwise), which means that the pressure force on the surface of the soil from the side of the second trawl disk can either grow or fall. As far as the working disk is concerned, it is shown that the values of the angular velocity of its rotation for the greater magnitude of unevenness' lifting are smaller.

The obtained results are basic for studying the dynamics of the trawl (working body) during mine clearance, their reliability is confirmed by obtaining in the extreme case the results related to the kinematics of some flat mechanisms.

Keywords: mine trawls, working disk, kinematic parameters of movement of trawl elements.

UDC 623.4:629.36

DOI: https://doi.org/10.33577/2312-4458.21.2019.28-37

\author{
Ya. Khaustov ${ }^{1}$, D. Khaustov ${ }^{1}$, E. Lychkovskyi ${ }^{2}$, Ye. Ryzhov ${ }^{1}$, Yu. Nastishyn ${ }^{1}$ \\ ${ }^{1}$ Hetman Petro Sahaidachnyi National Army Academy \\ ${ }^{2}$ Lviv Danylo Halytsky National Medical University
}

\title{
IMAGE FUSION FOR A TARGET SIGHTSEEING SYSTEM OF ARMORED VEHICLES
}

Image fusion methods available in the literature, are designed for the office work, and are unsuitable for the use by a crew of an armored vehicle (AV). In addition, we show that the image fusion for target sightseeing system (TSS) of AVs has its own peculiarities in comparison with traditional approaches for civilian needs. We argue that for the needs of the TSS the concept of local contrast is more appropriate in comparison with the concept of integral contrast, on which the image quality indices designed for civilian needs, are based. We show that the most suitable for the needs of TSS is the fusion of multi-mode mono-temporal mono-view images synthesized from partial images 
at the pixel level from the visible and infrared channels. We have derived analytical expressions, which relate the local contrasts of the key points in the fused image synthesized with the simple and weighted algorithms of image fusion to the local contrast of these points in the partial images from the observation channels. From these relations we concluded that the local contrast of the image obtained via simple or weighted fusion methods is always lower than the contrast of the corresponding key points on one of the two partial images.

The specific feature of the images collected from the visible and infrared channels is that contrasts of key points on such partial images, as a rule, are of opposite signs. We show that the image fusion is not always reasonable. There are situations at which the image fusion worsens the quality of the fused image in comparison with that of partial images. We demonstrate that due to the opposite signs of the local contrasts of key points on the visible and infrared images, under certain conditions the contrast of the key points in the fused image can vanish, such that the key point might become invisible in the fused image, while being clearly visible in both partial images. The analytical expressions that determine the conditions for the reduction of contrast in image fusion by simple and weight aggregation algorithms are obtained. The conclusions derived from the obtained analytical relations for the local contrast in the fused image are confirmed and illustrated by modeling the image fusion in Mathematica.

Keywords: target sightseeing system, thermal imaging, image fusion.

\section{Introduction}

Modern armored vehicles (AV) are equipped with precision control and monitoring devices. As a result their combat capabilities are governed not only by material factors, such as the tactical and technical characteristics of machinery and weapons, but also to a large extent, by the intellectual factors, such as the effectiveness of the target sightseeing system (TSS) [1]. Improvement of the efficiency of the TSS can be achieved not only by the modernization of its material part, but also by the computerization of the procedures preceding the target destruction via the development of software.

\section{Analysis of recent publications}

One of the possibilities to increase the efficiency of the TSS is to optimize the target image on the gunner and commander monitors. Obviously, this possibility acquires a special significance in conditions of poor visibility. For this, in modern AV models, systems of optical devices capable of recording targets in different spectral ranges of electromagnetic radiation (EMR): visible (Vis), Infrared (IR) and Radar (Radio-location, RL), are installed. Although Vis, IR and RL signals by their nature are spectral varieties of EMR, the signal recording in these three bands is based on fundamentally different mechanisms for converting the EMR into an electrical signal. At present there is no universal sensitive element that would ensure high-quality image registration simultaneously in all spectral ranges. Three different devices are used to register images in the Vis, IR, and RL bands: a CCD camera, a thermal imager and radar, respectively. As a rule each of these devices is equipped with its own monitor. It is clear that three or even two monitors disperse the attention of the operator, especially the gunner, and he is forced to focus on one monitor that provides the most informative image of the target. In this case, information from other monitors will be useless. Solution of this problem is in the image fusion from different channels into one image. Another advantage of image fusion is the possibility of the enhancement of informativeness and quality of the fused image in comparison with those of the partial images from different channels.

Current research literature on the image fusion contains a large amount of information that is rapidly updated. A sufficiently complete review of literature in this direction is done in $[2,3]$. However, it should be noted that the vast majority of image fusion methods, by default, are designed for the office work and often require special mathematical and computer training, and therefore, obviously, are unsuitable for use at the level of AV crews. In addition, below, we show that the use of image fusion for the TSS needs has its own specificity, which imposes additional requirements for the methods and algorithms of image fusion.

\section{Aim of the article}

Analysis and selection of methods and algorithms of image fusion, suitable for the use in TSS, is one of the tasks of this work. There is practically no special literature in this area. This is largely due to the fact that relevant foreign literature sources are closed to public access, while the information from the domestic closed and open publications is scarce. In this respect, the analysis of the modern methods of image fusion and selection of those methods, which are most suitable for the TSS needs, is in great demand. The most suitable and already used for the TSS in modern AV samples is the fusion of images from the visible and infrared channels. In the next section of the article, we focus on the features of the fusion of images from the CCD camera and the thermal imager in terms of their suitability for use in the operation of the TSS.

To optimize a fused image, one needs to perform the evaluation of the quality of the fused image (EQFI). The EQFI methods available in the literature, again, in their vast majority are designed for the office use and are practically unsuitable for the use by the crew of the 
$\mathrm{AV}$ in field conditions. Therefore, the next task, which is solved in section 2 of this work, is the analysis of existing EQFI methods for their suitability for TSSs and the development of simple mathematical criteria for EQFI suitable for implementation in TSSs.

\section{Results}

\section{Methods of image fusion in terms of their suitability for the needs of TSS}

In an electronic format, image fusion can be done by computer operations with data tables The partial input images can be of different origin, namely: 1) mono-or multi-modal, being obtained from one sensor or from sensors of different types, such as Vis, IR, RL, ultrasound (US), X-ray (XR); 2) mono- or multi-temporal, being obtained at the same or at different time moments; 3) mono- or multi-view, being obtained from one or different points of observation; 4) mono- or multi-focus; 5 ) in the form of raw or pre-processed data, such as noising/denoising, contrast-bright changes, changes in color characteristics, etc.

In the literature, methods of image fusion are classified by different criteria [2]. In the review article [2] five groups of such criteria are distinguished. We will focus only on classifications which are directly related to the task of this work, being important from the point of view of their suitability for the needs of TSS, namely: we consider the classification of image fusion methods by the origin of data and by the level of abstraction.

\subsection{Classification of image fusion methods by data origin}

In [4], see also [3], by the origin of data, the methods of image fusion are separated into six groups, which, according to the image classification mentioned in the previous section, we present in a somewhat modified form, which in our opinion more accurately reflects the essence of the classification of fused images, which by their origin are: 1) mono-modal mono-temporal multiview; 2) multimodal mono-temporal mono-view; 3) mono-modal mono-view multi-temporal; 4) mono-modal mono-temporal mono-view multi-focus; 5) pre-processed (noised or distorted); 6) with reduced resolution.

In fact, such a classification is rather conditional and may be supplemented by other combinations of images based on data origin, alluded to above. Such a variety of methods of image fusion can be useful for the office use, while for the needs of TSS one expects that the image fusion methods meet the following basic criteria: 1) ease of use; 2) mandatory expression of qualitative characteristics through quantitative parameters and mathematical algorithmization, which excludes subjective influence of the operator; 3) the computation speed, sufficient for real-time image processing.
Among the above six groups of methods, only the one, namely fusion of multi-modal, mono-temporal mono-view images, meets all these criteria. In other words, we are led to conclude that for the needs of the TSS installed on an AV, it should be recommended to fuse the raw images received from different channels (Vis, IR, and RL) at the same time moment from the same point of observation.

\subsection{Classification of image fusion methods by} level of abstraction

By the level of abstraction, one distinguishes the image fusion at the levels of 1) relevant attributes, 2 ) channel decision and 3 ) pixels. The first two groups of methods (relevant attributes and channel decisions) involve a subjective component implying the need for decision making by the operator and requires special knowledge of the theory of image processing. Such methods can have advantages in terms of office work, when elements of scientific intuition and art creativity are introduced into the process of image fusion. For military needs, especially in combat situations, when possibilities and time for decision making are very limited, the pixel fusion methods based on computer algorithms of mathematical operations with data tables should be used.

Pixel image fusion methods allow one to express the qualitative characteristics of the image by quantitative indices, to select the most important of them and to formulate on their basis the criteria of the EQFI. In section 2, we demonstrate how basing on the concept of local contrast of an image point one can predict the local contrast of the same image point in the fused image, knowing the local contrasts of this point in the partial images.

Pixel image fusion consists in mathematical operations with pixel brightness tables of the partial image according to certain algorithms. Any image obtained in the electronic format can be represented by a brightness table. In Mathematica [5], the brightness values of the pixels in the table are between 0 and 1 . Fifteen algorithms of pixel fusion are listed in [4] (similar classification is given in [3]). To this list one can add a method based on the wavelet transform developed in [3].

\subsection{Alignment of partial images}

The next feature of image fusion from the point of view of its application for the TSS relates to the informativeness of the fused image. Not all of the elements of the image, displayed on the TSS monitors, are equally important. Only certain elements of the image, namely: target and reference points, are important to the gunner and commander of the combat vehicle crew. Under the reference points, we understand highcontrast stationary image elements that serve for determination of the coordinates of the target. Target and reference points will be called the key points.

It is important to note that the key point of the image is an important notion in the theory of image fusion in a somewhat different meaning. To make the 
image fusion possible and effective, it is necessary to perform the coordinate and time alignment (also called registration) such that the key points of the image in of one channel should be superimposed by their coordinates with the same points on another partial image.

\section{EQFI by the local contrast of the key points}

\subsection{Concept of integral and local contrasts}

At present, the quality of image fusion remains to be an open issue [6]. Two groups of methods for assessing the quality of the fused image, namely: subjective and objective methods are available in the literature. The subjective methods are based on human perception of images such that useful information is obtained via a survey of potential users. Subjective methods are capable to improve significantly the image fusion since they imply user feedback, but they are not suitable for computerization of the image fusion process and cannot be applied to the needs of the TSS. To avoid the subjectivity in the EQFI, the qualitative characteristics of the image should be described by the measurable quantitative parameters.

EQFI methods based on the calculation of various indicators characterizing the amount of information transferred to the fused image were proposed in [7 and references herein]. The values which characterize averaged brightness changes in the image with respect to the average brightness value are usually calculated, instead of comparison of a fused image to a reference images. In other words the quality of the fused image is characterized using the notion of the contrast averaged over a certain region.

Contrast, which is averaged over a certain relatively large area of the image or throughout the image, will be called the integral contrast. Practically, all EQFI methods available in the literature operate with the notion of integral contrast, which is included in different forms in various offered in the literature indices of the quality of the fused image. However, an important feature of the images received from the TSS channels, is that in most cases the useful information is concentrated in the vicinity of key points, while the information from the rest larger part of the image is irrelevant, being of no interest. In addition, in poor visibility, a large part of the image might be darkened being of low contrast. Such a situation is typical at thermal imaging, at which the observed objects are seen on a dark background, which sometimes occupies a predominant part of the area of the image. This situation is especially pronounced at radar scanning, for which the observed object is typically seen in the form of bright spots on a dark background of a much larger area. Another extremity might be the lightsaturation (also called blooming) of a Vis or IR image. The predominantly darkened or light-saturated background carries irrelevant information which masks the contribution of the useful information to the quality metrics of the fused image. In such cases, the integral quality indices, including integral contrast, are inappropriate, since they will largely be affected by the information from irrelevant areas. If the image contains more than one key point and they are scattered across the image, the problem of the impact of irrelevant areas on the image quality indices cannot be solved by cropping the irrelevant areas. For this reason, in such cases, the local contrast of the key points with respect to their nearest vicinity is preferable rather than the notion of integral contrast.

Thus, we are led to conclude that for the needs of the TSS, simple EQFI criteria, applied to the key points are needed. These criteria should provide the EQFI processing in real time, without retardations.

One of the most important image quality criteria is the maximum contrast of key points with respect to their background. The high contrast criterion is more important than the criterion of high brightness. With high image brightness, but low contrast, the key point might be poorly visible in the image. However, by definition, the notion of high contrast as such implies high brightness either of the background, on which the dark key point is observed or high brightness of the key point on a dark background. We did not find in the literature analytic expressions relating the local contrast of a point in a fused image to the local contrasts of the same point in partial images. For this reason, we consider below the dependence of the local contrast of the point on the fused image on the local contrasts of the same point on the input partial images, which are fused using the algorithms of simple and weighted fusion.

It should be recalled that for the needs of the TSS the image fusion is employed at the conditions of poor visibility of key points. In such cases, the texture details of the observed objects are usually indistinguishable, and the observed objects themselves look as dark (bright) figures or spots on the brighter (darker) background when viewed using a conventional CCD camera (thermal imager) in the visible (respectively, infrared IR) light. Therefore, in typical cases of image fusion for the TSS there is no need to involve the definition of the contrast of the observed object via coordinate derivatives of the spatial distribution of image brightness. Instead it is sufficient to consider the notion of discrete contrast of the observed object as a whole with respect to the background, on which it is observed. Assuming that the brightness weakly changes within the area encircled by the object contour, we choose a point with coordinates $x, y$ inside the object area. In the pixel format of the image, the selected point represents a single pixel and the numbers $x$ and $y$ correspond to the numbers of the row and column, respectively, in which the given pixel is located. To determine the local contrast of a key point with coordinates $x, y$, we choose another point with coordinates $x+\Delta x, y+\Delta y$ in its neighborhood, which corresponds to the point of the background. Then the 
contrasts of the point with coordinates $x, y$ in the images obtained from the two channels $A$ and $B$ are determined respectively as

$$
k^{A}=\frac{\Delta u}{\bar{u}} ; \quad k^{B}=\frac{\Delta v}{\bar{v}},
$$

where

$$
\begin{aligned}
& \Delta u=u x+\Delta x, y+\Delta y-u x, y ; \\
& \bar{u}=\frac{u x+\Delta x, y+\Delta y+u x, y}{2} ; \\
& \Delta v=v x+\Delta x, y+\Delta y-v x, y ; \\
& \bar{v}=\frac{v x+\Delta x, y+\Delta y+v x, y}{2} .
\end{aligned}
$$

Taking into account that $u$ and $v$ can take values within the interval $[0 ; 1]$, from expressions (1), (2) we find that the local contrast takes the values within the interval [$2 ; 2]$. In the next sections, we will evaluate the contrasts of the point in a fused image for the simple and weighted image fusion algorithms.

\subsection{Simple fusion: $S$-image}

At simple image fusion (SIF), the brightness in the pixels of the images from the channels $A$ and $B$ are summing up, and consequently the brightness of the point in the fused image is of the form

$$
\psi^{s} x, y=u x, y+v x, y .
$$

It follows from Eq. (3) that the fusion of images leads to the increase of the brightness of the fused image in comparison with the brightness of the partial images. However, one should keep in mind that the pixel brightness of a computer image is defined by gradation within a certain interval with some maximum value $\psi_{\max }$. In some computer programs $\psi_{\max }=255$. In other programs, such as Mathematica, brightness values are between 0 and 1 . The summation of brightness by algorithm (3) implies a situation at which the total value of brightness $\psi^{s}$ will be higher than $\psi_{\max }$. In such a case Mathematica replaces all values $\psi^{s}>\psi_{\max }$ by $\psi_{\max }$. Obviously, the truncation of the brightness values higher than $\psi_{\max }$, results in a considerable reduction of contrast, even up to zero. To overcome this problem, one introduces weight factors $w^{A}$ and $w^{B}$.

The approach of weighted fusion is discussed in the next section. Within this section, we will analyze the contrast of the image obtained with the algorithm of simple fusion, i.e at $w^{A}=w^{B}=1$. For the algorithm of simple fusion from Eqs. (1) and (2), we find:

$$
k^{s}=\omega^{u} k^{A}+\omega^{v} k^{B},
$$

where $\omega^{u}=\bar{u} / \bar{u}+\bar{v} \quad$ and $\quad \omega^{\mathrm{v}}=\bar{v} / \bar{u}+\bar{v} \quad$ are the relative values of brightness of the key point in the images from the channels $A$ and $B$. We will call the parameter $\omega^{u}$ (respectively $\omega^{v}$ ) the weight of the image $u$ (respectively $v$ ) in the fused image. It is clear that $\omega^{u}+\omega^{v}=1$ and, consequently, (4) takes the form

$$
k^{s}=k^{A}-\Delta k \omega^{\mathrm{v}}=k^{B}+\Delta k \omega^{u},
$$

where $\Delta k=k^{A}-k^{B}$.

It is important to note that, depending on the sign of $\Delta u$ (or $\Delta v$ ), the value of the contrast in the image from the channel $A$ (respectively $B$ ) can take either a positive $k^{u}>0$ (respectively $k^{\mathrm{v}}>0$ ) or negative $k^{u}<0$ (respectively $k^{\mathrm{U}}<0$ ) value. The positive (negative) contrast value corresponds to the situation when $\Delta u, \Delta v>0$ (respectively $\Delta u, \Delta v<0$ ), which corresponds to the dark (bright) object of the target observed on the bright (dark) background. For a visible image, as a rule, the target absorbs light, and consequently one has a black target on a bright background, and consequently $k^{u}>0$. For a picture from the thermal camera, as a rule, on the contrary, the target emits IR-waves. Consequently, the bright target is observed on a black background, and thus $k^{\mathrm{v}}<0$. The behavior of the contrast given by Eq. (4) for different $k^{u}$ with respect to $k^{\nu}$ is shown in Fig. 1. If both images are received from the same channel, then both contrasts are of the same sign, for example $k^{u, v}>0$, for the visible channel.

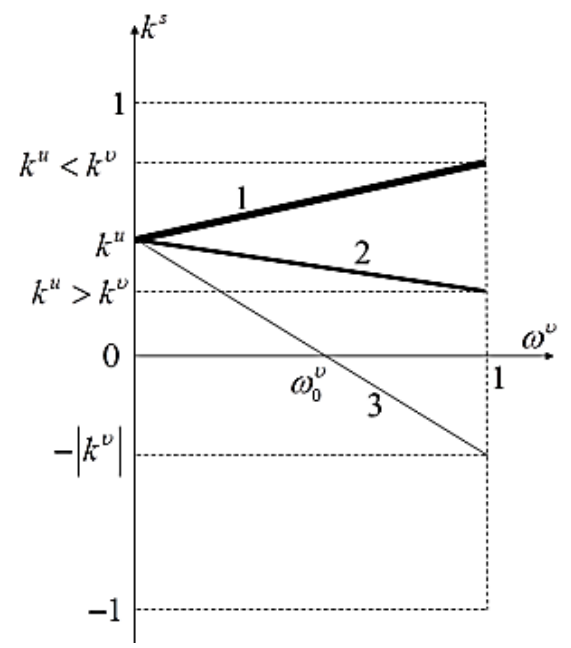

Fig. 1. Dependence of the contrast $\boldsymbol{k}^{s}$ (solid lines) of the fused image on the weight parameter $\omega^{\mathrm{v}}$ for different ratios between contrasts $\boldsymbol{k}^{\boldsymbol{u}}$ and $\boldsymbol{k}^{\mathrm{U}}$ of the input partial images: $k^{u, v}>0, k^{u}<k^{\cup}(1$, thick line); $k^{u, \cup}>0, k^{u}>k^{\cup} \quad(2$, medium-thickness line); $\boldsymbol{k}^{u}>0, \boldsymbol{k}^{\mathrm{U}}<0(3$, thin line $)$

If $k^{u}<k^{\mathrm{v}}$, then the contrast of the fused image increases linearly (thick line 1) with the increase of the weight parameter $\omega^{\mathrm{v}}$ from $k^{u}$ at $\omega^{\mathrm{v}}=0$ to $k^{u}$ at 
$\omega^{v}=1$. If for two visible images (i.e. for $k^{u, v}>0$ ) one has $k^{u}>k^{\mathrm{v}}$, then the contrast of the fused image decreases with the increased $\omega^{\mathrm{v}}$ (line 2).

If the image is received from different channels, for example, Vis and IR, then we have $k^{u}>0 ; k^{\mathrm{v}}<0$ and then with the change of $\omega^{v}$ the value $k^{s}$ varies from $k^{u}$ to $-\left|k^{v}\right|$ (thin line 3).

The case $k^{u}>0 ; k^{\mathrm{v}}<0$ is illustrated in Fig. 2 by the fusion of the images of a dark square on a bright background $\left(k^{u}>0\right)$ which models an image received from a CCD camera in the visible light and a bright square on a dark background $\left(k^{v}<0\right)$ which models the image from the thermal camera. In Mathematica, such images are modeled by the data tables:

$$
\begin{aligned}
u & =\left[\begin{array}{lllll}
0.8 & 0.8 & 0.8 & 0.8 & 0.8 \\
0.8 & 0.8 & 0.8 & 0.8 & 0.8 \\
0.8 & 0.8 & 0.4 & 0.8 & 0.8 \\
0.8 & 0.8 & 0.8 & 0.8 & 0.8 \\
0.8 & 0.8 & 0.8 & 0.8 & 0.8
\end{array}\right], \\
u & =\left[\begin{array}{lllll}
0.4 & 0.4 & 0.4 & 0.4 & 0.4 \\
0.4 & 0.4 & 0.4 & 0.4 & 0.4 \\
0.4 & 0.4 & 0.8 & 0.4 & 0.4 \\
0.4 & 0.4 & 0.4 & 0.4 & 0.4 \\
0.4 & 0.4 & 0.4 & 0.4 & 0.4
\end{array}\right],
\end{aligned}
$$

where the brightness values of the dark and bright areas are taken accordingly $u_{1}=u \quad x, y=0.4$, $u_{2}=u \quad x+\Delta x, y+\Delta y=0.8$ and $v_{1}=v x, y=0.8$, $\mathrm{v}_{2}=v x+\Delta x, y+\Delta y=0.4$. For real images, these values can vary within the range from 0 to 1 . Images plotted by Mathematica for data (6) are shown in Fig. 2 with the corresponding tables superimposed on them.

\begin{tabular}{|c|c|c|c|c|}
\hline 0.8 & 0.8 & 0.8 & 0.8 & 0.8 \\
\hline 0.8 & 0.8 & 0.8 & 0.8 & 0.8 \\
\hline 0.8 & 0.8 & 0.4 & 0.8 & 0.8 \\
\hline 0.8 & 0.8 & 0.8 & 0.8 & 0.8 \\
\hline 0.8 & 0.8 & 0.8 & 0.8 & 0.8 \\
\hline
\end{tabular}

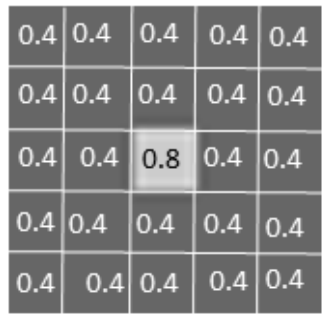

Fig. 2. Images corresponding to the tables (6) with the corresponding values superimposed on them

Using the tables (6), in Fig. 3 we illustrate the dependence $k^{s} \omega^{\mathrm{v}}$ given by Eq. (5). Taking into account that the fused image is formed by the sum of images from two channels, the maximum possible value of the brightness of the fused image is equal to $2 \psi_{\max }$ To overcome the effect of light-saturation in the case $\psi_{s}>\psi_{\max }$, we normalize the value $\psi_{s}$ dividing it by the maximum possible value of the fused image. Then the normalized brightness value is defined as $\psi_{\text {norm }}^{s}=\psi^{s} / 2 \psi_{\max }^{s}$.

Fig. 3 illustrates two important conclusions. For the algorithm of simple fusion of images:

1) the contrast of the fused image is always lower than the contrast of one of the two partial images;

2) if the contrasts of the partial images are of opposite signs (as in the case of fusion of images from the Vis and IR channels), then at a certain value

$$
\omega_{0}^{\cup}=\frac{k^{A}}{k^{A}-k^{B}}
$$

the contrast of the fused image becomes zero, $k^{s}=0$.

In Fig. 3 we take that $k^{A}=-k^{B}=2 / 3$, and, thus, have for these values $\omega_{0}^{\mathrm{v}}=0.5$. Indeed, in the image corresponding to $\omega^{\mathrm{v}}=\omega_{0}^{\mathrm{v}}=0.5$ (Fig. 3), the small square in the center became invisible against the background of the larger square for both representations $w^{A}=w^{B}=1$ and $w^{A}=w^{B}=1 / 2$.

For other values $k^{A}$ and $k^{B}$, the parameter can take any other values in the interval between 0 and 1 in accordance with Eq. (7). Thus, the algorithm of simple fusion leads to the increase of the brightness of the fused image, while the contrast of the fused image reduces. Moreover, if the contrasts of the partial images are of opposite signs, as is the case of the images from the $V$ is and IR channels, then at a certain value $\omega^{v}=\omega_{0}^{v}$ the contrast of the fused image vanishes to zero. Then two reasonable question arise: 1)"What is the advantage of the image fusion?" and 2) Is the image fusion always reasonable?

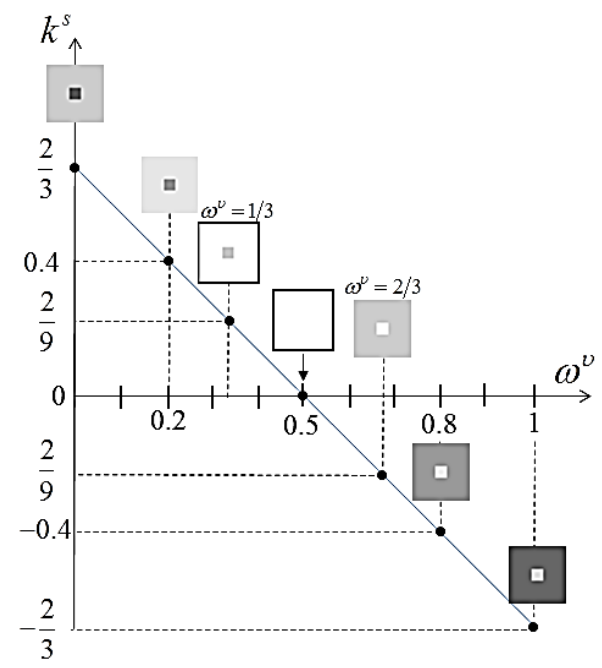

Fig.3. Dependence of the contrast $k^{s} \omega^{\mathrm{v}}$ of the fused image, illustrated by the corresponding fused images 
The advantage of a fused image appears if one takes into account simultaneously the contrast in several points of the image. Let us consider the contrasts of the key points 1 and 2 in the fused image. One of them (for example, the point 1 belongs to the target. Therefore, we will call the point 1 the target point. Another point (correspondingly, point 2 will serve as a reference point for setting the target's position with respect to it. Therefore the point 2 is called the reference point. In principle, one can choose not one but several reference points.

Let the key points and their contrasts be noted with the corresponding superscripts 1 and 2 , such that for the increasing weight parameter $\omega^{\mathrm{v}}$, the contrasts vary correspondingly along the solid lines 1 and 2 in Figs. $4 \mathrm{a}, \mathrm{b}, \mathrm{c}$.

If lines 1 and 2 do not intersect in the domain of permissible values $0<\omega^{v}<1$ of the weight parameter, then from Fig. $4 \mathrm{a}$ it is clear that there is no reason in the fusion of images, because the contrast of both points in the fused image is always lower than in one of the input images (Fig. 4a).

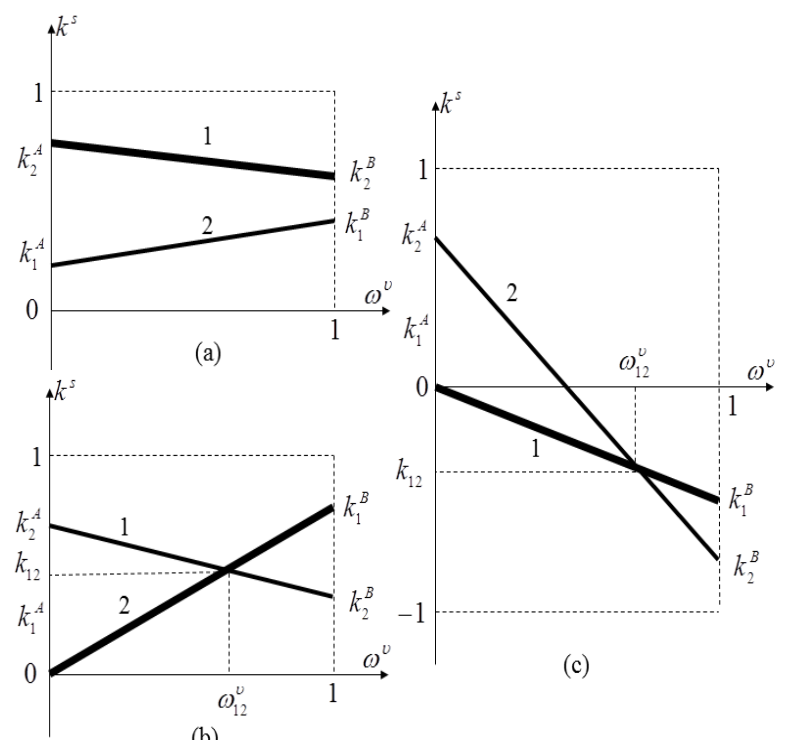

Fig. 4. Examples of dependence of the contrast on the weight parameter for two key points: the dependences $a$-do not intersect with $\boldsymbol{k}_{1}^{\boldsymbol{s}}>0, \boldsymbol{k}_{2}^{\boldsymbol{s}}>0, b$ - intersect with

$$
\begin{gathered}
\boldsymbol{k}_{1}^{\boldsymbol{s}}>0, \boldsymbol{k}_{2}^{\boldsymbol{s}}>0, c-\text { intersect with } \boldsymbol{k}_{1}^{\boldsymbol{A}} \neq 0, \boldsymbol{k}_{2}^{\boldsymbol{A}}=0 ; \\
\boldsymbol{k}_{1}^{\boldsymbol{B}}=0, \boldsymbol{k}_{2}^{\boldsymbol{B}} \neq 0
\end{gathered}
$$

If in the domain of the permissible values of the weight parameter $\omega^{v}$ the lines 1 and 2 do intersect, then at the increase of the weight parameter, the contrast of one point decreases, while for the other one it increases (Fig.4b). If the visibility of both key points is equally important, then the optimal value of the weight parameter is

$$
\omega_{1}^{\mathrm{v}}=\Delta k^{A} / \Delta k^{B}-\Delta k^{A},
$$

which corresponds to the abscissa of the point of intersection of lines 1 and 2 (Fig.4b), with the subscript indices 1 and 2 correspond to the points 1 and 2 in the images $A$ and $B$.

The ordinate of the point of intersection of lines 1 and 2 is defined as

$$
k_{12}=\frac{k_{1}^{A} \Delta k_{2}-k_{2}^{A} \Delta k_{1}}{\Delta k_{2}-\Delta k_{1}} .
$$

It follows from Eq. (9) that if one of the points, for example, point 2 , is invisible in one of the images, for example, in the image from the channel $A$, because it is of zero contrast (i.e, one has $k_{1}^{A} \neq 0, k_{2}^{A}=0$ ), while in the image from the channel $B$ the same point 2 is well visible, but instead the point 1 is invisible (i.e., one has $k_{1}^{B}=0, k_{2}^{B} \neq 0$ ), then in the fused image, both points 1 and 2 are visible and are of the same contrast (Fig. 4b), which is determined by Eq. (9). The very this simultaneous visibility of the two points on the fused image is the advantage of the image fusion. In other words the image fusion provides the simultaneous visualization of the key points such that points which are invisible or of low contrast in one of the partial images become visible in the fused image together with other key points.

The same conclusions are valid for the case if one image is received from the Vis channel, and the other one from the IR channel (Fig. 4c). An example, when in the Vis and IR images two different points are seen, such that one of them is seen only on the Vis image and the other one only on the IR image, while both points are visible in the fused image, is shown in Fig. 5.
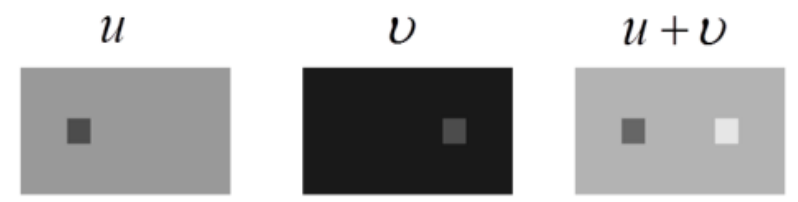

Fig. 5. Computer modeling of the image fusion, which illustrates its advantage

If in the fused image we have several reference points, then the value of the weight parameter $\omega^{v}$ should be chosen such that the number of reference points and their mean contrast are maximal.

Thus we are led to one more conclusion: the best fused image corresponds to the highest contrast of the target at the largest number of reference points of maximum contrast observed in the fused image.

\subsection{Weighted fusion: $w$-image}

In the previous section, it was noted that, at the condition $\psi^{s}>\psi_{\max }^{s}$ the fusion of images might lead to the effect of light-saturation. To avoid this effect, one introduces the weight factors $w^{A}$ and $w^{B}$ such that 
$w^{A}+w^{B}=1$, the brightness of the fused image will be determined by the equation

$$
\psi^{w}=w^{A} u+w^{B} v=u-w^{B} \quad u-v=v+w^{A} u-v .
$$

In other words, in contrast to the simple fusion, discussed in the previous section, in this section we deal with the algorithm (10) of weighted image fusion. From Eqs. (1), (2) we find that the contrast of the fused image corresponding to the weighted fusion given by Eq. (10) is of the form

$$
k^{w}=k^{A} \omega^{u w}+k^{B} \omega^{v w},
$$

in which

$$
\begin{aligned}
& \omega^{u w}=\frac{w^{A} \omega^{u}}{w^{A} \omega^{u}+w^{B} \omega^{v}}, \\
& \omega^{v w}=\frac{w^{B} \omega^{v}}{w^{A} \omega^{u}+w^{B} \omega^{v}} .
\end{aligned}
$$

Thus, the contrast $k^{w}$, Eq. (11), for the weighted image fusion is of the same form as that of $k^{s}$, Eq. (4), for the simple fusion, with the difference that in $k^{w}$, Eq. (11), the weight parameters $\omega^{u}$ and $\omega^{v}$ of the partial images are normalized (multiplied) by the corresponding weighted factors $w^{A}$ and $w^{B}$. For arbitrary values of weight coefficients $w^{A} \neq w^{B}$ one has $w^{A} \omega^{u}+w^{B} \omega^{\mathcal{U}}<1$. However, from (12) and (13) it is obvious that the sum of the normalized weight parameters is equal to one

$$
\omega^{u w}+\omega^{v w}=1
$$

Using (14), we rewrite the equation (5) to the form

$$
k^{w}=k^{A}-\Delta k \omega^{v w}=k^{B}+\Delta k \omega^{u w},
$$

where as before $\Delta k=k^{A}-k^{B}$. In both cases, when the weighted factors are equal, namely, at $w^{A}=w^{B}=1$ and $w^{A}=w^{B}=1 / 2$ Eqs (11) and (15) reduce to Eqs. (4) and (5), respectively. Furthermore, it was shown above that at simple fusion the contrast is the same independently which of the two conditions $w^{A}=w^{B}=1$ or $w^{A}=w^{B}=1 / 2$ is applied. The brightness is different in these two cases, but not the contrast. In other words, the simple fusion is a partial case of the weighted fusion, which corresponds to $w^{A}=w^{B}$.

It follows from (15) that in the case of the fusion of Vis and IR images using the algorithm of the weighted fusion, due to the fact that $k^{A}>0, k^{B}<0$ the contrast $k^{w}$ of the fused image, as in the case of simple fusion, is not higher than one of the contrasts $k^{A}$ or $k^{B}$ of the partial images. However, at the weighted fusion the dependencies $k^{w}\left(\omega^{\mathrm{v}}\right)$ and $k^{w}\left(\omega^{u}\right)$ are no more linear. To show this, we substitute (12), (13) into (15)

$$
k^{w}=k^{A}-\Delta k \frac{w^{B} \omega^{v}}{w^{A} \omega^{u}+w^{B} \omega^{v}}=k^{B}+\Delta k \frac{w^{A} \omega^{u}}{w^{A} \omega^{u}+w^{B} \omega^{v}}
$$

Dependencies $\quad k^{w}\left(\omega^{\mathrm{v}}\right)$ for different values $0<w^{B}<1$ are shown in Fig. 6. From Fig. 6 it is seen that for different values $w^{B}$ the contrast of the fused image vanishes at different values

$$
\omega_{0}^{\cup}=\frac{k^{A} 1-w^{B}}{k^{A} 1-w^{B}-k^{B} w^{B}} .
$$

For example, for $w^{B}=0.2$ from (17) we find a value $\omega_{0}^{\mathrm{v}}=0.8$ which can be clearly identified in Fig. 6 .

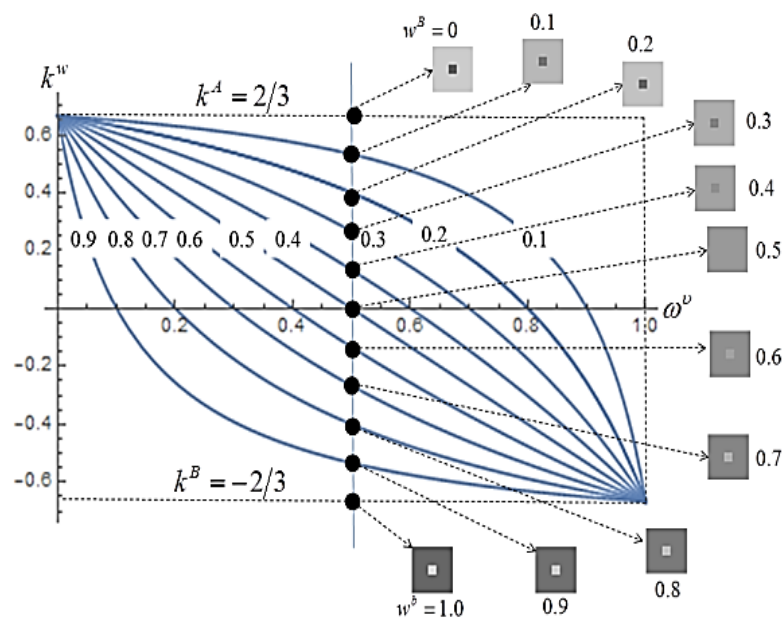

Fig. 6. Dependencies $\boldsymbol{k}^{\boldsymbol{w}}\left(\omega^{\mathrm{v}}\right)$ at $\boldsymbol{k}^{\boldsymbol{A}}=2 / 3, \boldsymbol{k}^{\boldsymbol{B}}=-2 / 3$

for different values $0<w^{B}<1$ indicated on the corresponding curve

\section{Conclusions}

Improvement of the effectiveness of the target sightseeing system of armored vehicles can be achieved by improvement of the image of target on the gunner and the commander monitors by the fusion of images from different observation channels. For the TSS needs, the partial images can be obtained in visible and infrared spectral ranges. It is also promising to use the image of the target received from radar. Fusion methods available in the literature, by default, are designed for the work in the office, imply special knowledge and skills of the operator in programming, and therefore are unsuitable for the use by a crew of an AV.

Image fusion for TSS has its own peculiarities in comparison with traditional approaches for civilian needs. The difference is that for civilian needs 
the quality of the image as whole is important, while only elements of the image, namely, the key points are important for the needs of the TSS. The image quality indices, which are designed for civilian needs, are based on the concept of integral contrast. In this paper, we have shown that for the needs of the TSS the concept of local contrast is more appropriate, since it allows for tracing the contrasts of the key points, thereby excluding from consideration the contributions of the irrelevant areas of the image.

We argue that for the needs of TSS one has to employ such image fusion methods, which exclude subjective evaluations of the quality of the partial and fused images by the operator, minimize the participation of the operator in the formation of the fused image, enable the real time monitoring of the observations involving fusion of images from different channels, increase the informativeness of the fused image via enhancement of the contrast of key points of the image.

We show that the most suitable for the needs of TSS is the fusion of multi-mode mono-temporal monoview images synthesized from partial images at the pixel level. The most suitable for the fusion in the TSS are images from visible and infrared channels, although promising, but still little studied is the fusion of images from these two channels combined with that from the radar channel.

We have derived analytical expressions, which relate the local contrasts of the key points in the fused image obtained employing the simple and weighted algorithms of image fusion to the local contrast of these points in the partial images from the observation channels.

From these relations we concluded that the local contrast of the image obtained via simple or weighted fusion methods is always lower than the contrast of the corresponding key points on one of the two partial images. The specific feature of the images collected from the visible and infrared channels is that contrasts of key points on such partial images, as a rule, are of opposite signs. We show that the image fusion is not always reasonable. There are situations at which the image fusion worsens the quality of the fused image in comparison with that of partial images. We demonstrate that due to the opposite signs of the local contrasts of key points on the visible and infrared images, under certain conditions the contrast of the key points in the fused image can vanish, such that the key point might become invisible in the fused image, while being clearly visible in both partial images. The analytical expressions that determine the conditions for the reduction of contrast in image fusion by simple and weight aggregation algorithms are obtained.
The conclusions derived from the obtained analytical relations for the local contrast in the fused image are confirmed and illustrated by modeling the image fusion in Mathematica. In particular we have modeled the situation at which the contrast of the object vanishes in the fused image, although on both partial images it is well visible. We have modeled also the situation at which an object is visible only on one partial image, while the other object is visible only on the second partial image, but both objects become simultaneously visible on the fused image. This example illustrates the case, when the informativeness of fused images increases in comparison with that of the partial images and highlights the advantage of the image fusion.

\section{References}

1. Khaustov Ya.Ye. Current state and prospects for the further development of the sighting systems of armoured force vehicles / Ya.Ye. Khaustov, D.Ye. Khaustov, Yu.A. Nastishin, V.Iv. Gordienko, Ye.V. Ryzhov // Development and modernization military equipment. Military technical collection. - Lviv, 2019. no. 20 - P. 48-57. DOI: https:// doi.org/10.33577/23124458.20.2019.48-57

2. Castanedo F. A Review of Data Fusion Techniques / F. Castanedo // The ScientificWorld Journal. - 2013. - 19p. Article ID: 70450, DOI: http://dx.doi.org/10.1155/2013/ 704504

3. Hryvachevskyi A.P. Improving the informativeness of multispectral monitoring systems by image fusion of the visible and infrared ranges: A thesis submitted in fulfilment of the Ph.D. degree in technical sciences: 05.12.17 / Hryvachevskyi Andrei Petrovich; Lviv Polytechnic National University. - Lviv, 2018. - 170 p.

4. Kolobrodov V. Research and practice aspects of creation of the thermal imaging systems / V. Kolobrodov, V. Gordienko, V.Mykytenko, I. Mazurin, S. Klufas. Cherkasy: Vertykal, 2015. $-150 \mathrm{p}$

5. Wolfram S. The Mathematica Book: 5th ed. / S. Wolfram. - New York: Wolfram Media, 2005. - 1486 p.

6. Smith M.I. Review of Image Fusion Technology in 2005 / M.I. Smith, J.P. Heather // Proceedings of the SPIE. 2005. - vol. 5782. - P. 29-45. DOI: https://doi.org/ $10.1117 / 12.597618$

7. Winkler S. Special issue on image and video quality metrics / S. Winkler, F. Dufaux, D. Barba, V. Baroncini // Signal Processing Image Communication. - 2010. - vol. 25, no.7. DOI: https://doi.org/10.1016/j.image.2010.07.001 


\title{
Особливості комплексування зображень з видимого та тепловізійного каналів
} прицільно-спостережного комплексу зразків бронетанкової техніки

\author{
Я.Є. Хаустов, Д.Є. Хаустов, Е.І. Личковський, Є.В. Рижов, Ю.А. Настишин
}

Запропоновані в літературі методи комплексування зображень розроблені для роботи в умовах офісу, а тому $є$ непридатними для застосування на рівні екіпажів бронемашин. Комплексування зображень для прицільноспостережних комплексів (далі-ПСК) зразків бронетанкового озброєння має свої особливості у порівнянні з традииійними підходами для циивільних потреб. В иій роботі ми показали, щуо для потреб ПСК конщепція локального контрасту більи придатна в порівнянні з концепцією інтегрального контрасту, яка є основою для показників якості зображення, розроблених для цивільних потреб. В статті вказано, щзо найбільш придатними для потреб ПСК $\epsilon$ комплексування різномодових одномоментних моноракурсних зображень на піксельному рівні. Найбільш придатними для комплексування в ПСК $є$ зображення із видимого та інфрачервоних каналів, а також перспективним, але поки що маловивченим є комплексування ичих двох каналів зображень із радіолокачійним каналом. Отримано аналітичні співвідночення, які пов'язують локальний контраст ключових точок комплексованого зображення із локальними контрастами ичих точок на париіальних каналах при комплексуванні за методами простого та вагового складання. Із циих співвідношень зроблено висновок, що локальний контраст зображення, комплексованого за методами простого чи вагового складання, $\epsilon$ завжди нижчим, ніж контраст відповідних ключових точок на одному із париіальних зображень.

Показано, що комплексування зображень не завжди є результативним. Внаслідок протилежності знаків локальних контрастів видимого та інфрачервоного зображень за деяких умов контраст ключових точок на комплексованому зображенні може занулюватися, тобто ключова точка може ставати невидимою на комплексованому зображенні, хоча при иььом вона чітко спостерігається на париіальних зображеннях. Отримано аналітичні вирази, які задають умови занулення контрасту при комплексуванні зображень за алгоритмами простого та вагового складання. Висновки, які випливають із отриманих аналітичних співвідношень для локального контрасту на комплексованому зображенні, підтверджено та проілюстровано за допомогою моделювання комплексування зображень в середовищі Маtheтаtica.

Ключові слова: прицільний комплекс, тепловізійна система спостереження, комплексування зображень.

\section{Особенности комплексирования изображений из видимого и тепловизионного каналов прицельно-наблюдательного комплекса образцов бронетанковой техники}

\section{Я.Е. Хаустов, Д.Е. Хаустов, Э.И. Личковский, Е.В. Рыжов, Ю.А. Настишин}

Методы комплексирования изображений, имеющиеся в литературе, предназначены для работы в офисе и непригодны для использования экипажем бронемашины. Комплексирование изображений для прицельнонаблюдательных комплексов (далее-ПСК) бронетанкового вооружения имеет свои особенности по сравнению с традиционными подходами для гражданских иелей. В этой работе мы показали, что для ПСК образиов бронетанкового вооружения концепция локального контраста более подходящая по сравнению с концепцией интегрального контраста, являющейся основой для показателей качества изображения, разработанных для гражданских иелей. В статье показано, что наиболее подходящим для ПСК является комплексирование разномодовых одномоментных моноракурсных изображений на пиксельном уровне. Наиболее приемлемыми для комплексирования в прицельнонаблюдательных комплексах являются изображения на пиксельном уровне с видимого и инфракрасного каналов. Получены аналитические соотночения, связывающие локальный контраст ключевых точек комплексированного изображения с локальными контрастами этих точек на парииальных каналах при комплексировании методами простого и весового сложения. Из этих соотношений мы пришли к выводу, что локальныий контраст изображения, полученного простым или весовым методом комплексирования, всегда ниже, чем контраст соответствующих ключевых точек на одном из парииальных изображений.

Показано, что комплексирование изображений не всегда является результативным. Из-за противоположных знаков локальных контрастов ключевых точек на видимых и инфракрасных изображениях при определенных условиях контраст ключевых точек на комплексированном изображении может зануляться, так что ключевая точка может стать невидимой на комплексированном изображении, хотя при этом она четко видна на обоих парциильных изображениях. Получены аналитические выражения, определяющие условия снижения контрастности при комплексировании изображений с помощью простых и весовых алгоритмов сложения. Выводы, сделанные на основе полученных аналитических соотношений для локального контраста на комплексированном изображении, подтверждены и иллюстрируются путем моделирования комплексирования изображений в среде Mathematica.

Ключевые слова: прицельный комплекс, тепловизионная система наблюдения, комплексирование изображений. 